\author{
Transport and Telecommunication Institute, Latvia \\ Olga Zervina \\ Transport and Telecommunication Institute, Latvia
}

\title{
TEACHING PROFESSIONAL ENGLISH AT A MODERN UNIVERSITY: PREPARING STUDENTS FOR THE GLOBAL LABOR MARKET
}

\begin{abstract}
Summary. The main concern for modern universities is to provide their graduates with a wide variety of skills required for the international job market, including excellent language skills. In this context, English language learning in a higher education institution is becoming an indispensable component of multidisciplinary education. A multidisciplinary study program is characterized by the integration of various areas; in the framework of such a program, different educational formats of learning both languages and professional subjects can be incorporated. In contemporary universities, the English language needs to be a competent language when it comes to teaching in the content areas of Management, Economics, Architecture, Human Rights, Information Technologies and many other specialized subjects. In a multidisciplinary program, each Professional English language course must meet the requirements of people who are going to use English as an international language in order to communicate efficiently in their particular area of expertise, and for whom using English at work would be essential for their career development. This paper addresses some of the major issues related to teaching Professional English at a modern university. The aim of this paper is to discuss a few innovative e-learning solutions to be utilized within the framework of a multidisciplinary educational program for increasing the graduates' proficiency in professional communication with the aim to prepare them for the global labor market. In the paper, it is argued that the blended approach to language learning shows great promise as an efficient tool for acquiring different language skills, the emphasis being put on applying English in real-life situations and in specialized fields.
\end{abstract}

Keywords: multidisciplinary education, Professional English, e-learning solutions, blended learning.

\section{Introduction}

In the context of ongoing globalization of the world economy and increasing importance of life-long learning, the main concern for modern universities is to provide their graduates with a wide range of skills necessary for the international job market, including excellent language skills. The European Union is based on the free movement of people, capital and services, so the EU citizens with good language skills are supposed to take advantage of the various opportunities offered by an integrated Europe (Com (2003) 449 final; Com (2007) 184 final). As contemporary universities play an essential role in promoting societal and individual multilingualism, higher education institutions should develop a clear language policy for promoting language learning and linguistic diversity 
(Com (2003) 449 final); generating a constructive language learning environment in universities has become a central aspect of language education in Europe (The Common European Framework of Reference for Languages: Learning, Teaching, Assessment, 2001).

Recently, the extensive use of ICT in higher education has led to the emergence of new e-learning environments and teaching formats; they are supposed to support computer-based and self-directed learning; they are intended for inspiring students' motivation and promoting their intellectual and professional development (Stukalina, 2014). These new educational formats, which integrate ICT into everyday classroom practices and provide access to the knowledge domains not available earlier, may contribute much to the development of different language skills in the framework of professional study programs, including Englishmedium programs. Such programs that are becoming increasingly popular in many European universities, as the English language needs to be a competent language when it comes to teaching in the content areas of Management, Economics, Architecture, Logistics, Human Rights, Information Technologies and many other specialized subjects.

The aim of this paper is to discuss a few innovative e-learning solutions to be utilized within the framework of a multidisciplinary educational program for increasing the graduates' proficiency in professional communication with the aim to prepare them for the global labor market. In the paper, it is argued that the blended approach to language learning (the integration of online and classroombased activities) shows great promise as an efficient tool for acquiring different language skills, the emphasis being put on applying English in real-life situations and in specialized fields.

\section{English language learning as an indispensable component of modern multidisciplinary education}

The educational programs designed for supporting multidisciplinary education are characterized by the interdisciplinary model for content and integration of topics (Evans, Goodnick, \& Roede, 2003). The intellectual synthesis is an essential aspect of such a program; it enables students to perceive their area of expertise holistically and provides new opportunities for students in the context of the job market customization (Stukalina, 2009). The main objectives of a modern 
multidisciplinary educational program include, among other things, promoting the acquisition of professional skills to help graduates get integrated in the world economy and language learning and intercultural awareness.

As the English language is spoken globally, it plays an essential role in many areas including the field of education. English language competence has become a key to global competitiveness, Professional English being an indispensable component of modern multidisciplinary education. Figure 1 illustrates the demand of eldercare professionals with excellent English skills. The Survey took place in the United States in 2009-2013, when a care providers' industry experienced a shortage of skilled professionals. It resulted in the great number of caregivers arrived from overseas. Moreover, many care workers are of Hispanic origin with English as a second language. As the Figure shows, excellent English skills lead to bigger paychecks (Four Year Salary Survey by Lifeworx, 2009-2013).

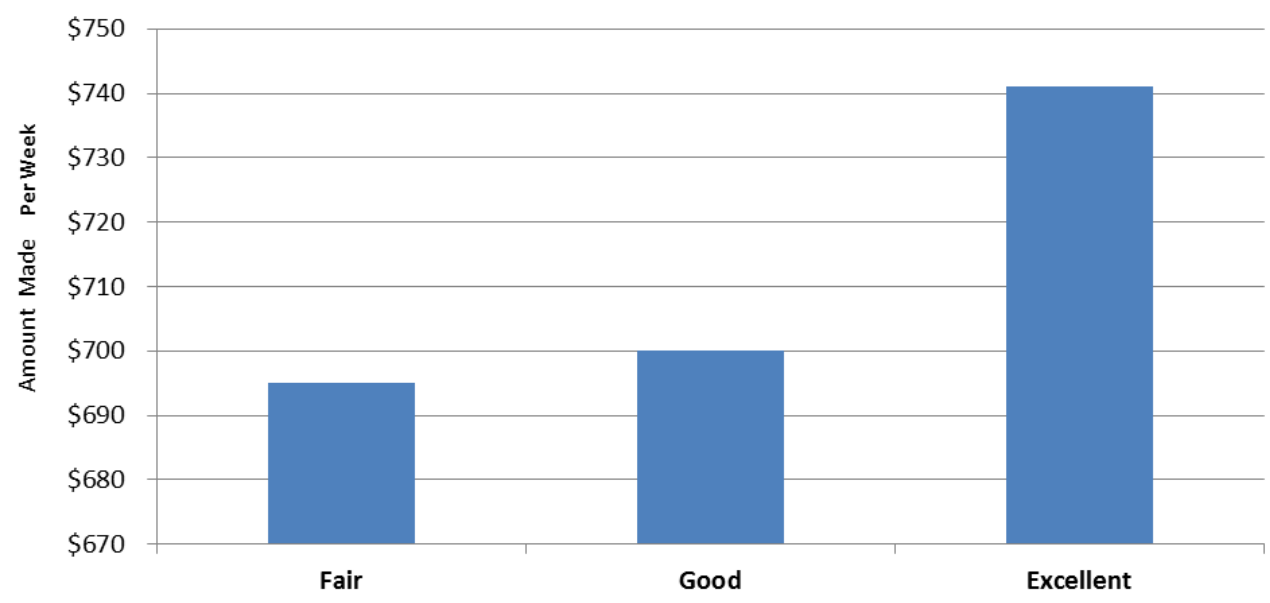

Fig. 1. Four Year Salary Survey by LifeWorx (2009-2013)

In different higher education institutions, the extent to which Professional English is incorporated in the multidisciplinary curricula may vary. Traditionally, universities offer Professional English courses as separate subjects: Professional English for Logistics, Professional English for Information Technologies, etc. However, we suppose that language learning should be performed in the framework of providing professional language solutions with strong support from teachers of special subjects. In a contemporary higher education institution, any 
TEACHING PROFESSIONAL ENGLISH AT A MODERN UNIVERSITY: PREPARING STUDENTS FOR THE GLOBAL LABOR MARKET

Professional English course ought to be designed to achieve specific educational objectives stated by the curriculum (Stukalina, 2011).

A more advanced model presupposes that several professional subjects are taught in English: Management, Economics, Computer Science, Information Technologies, Logistics, etc. Intensified cross-border higher education and mobility of students, as well as the increased international academic research dictate terms to modern universities (Higher Education to 2030: Globalisation, OECD, 2009). Now, for providing globally competitive standards of teaching, more and more European countries are offering English-medium educational programs (ETPS). According to the study conducted by German researchers (Lam \& Wächter, 2014), since 2001 there has been the exponential growth of the amount of ETPs across non-English-speaking Europe. The largest absolute number of ETPs was identified in the Netherlands $(1,078)$; following the Netherlands there are Germany $(1,030)$, Sweden (822), France (499), Denmark (494), and Poland (405).

Figure 2 illustrates an Institute of International Education (IIE) study (IIE.org, 2012). It shows that European institutions are offering more Englishmedium master's degrees to meet local and international student demand. The study analyzed MastersPortal.eu, a website where 960 EU universities post over 18,000 of their own master's degree programs. According to IIE Study, by October 2011, the number of English-medium programs listed at MastersPortal had risen to 3,701 ; the number of programs taught completely or partially in English had reached 4,664: $79 \%$ of the programs are taught totally in English, and $21 \%$ - in English and at least one other language (Brenn-White \& van Rest, 2012).

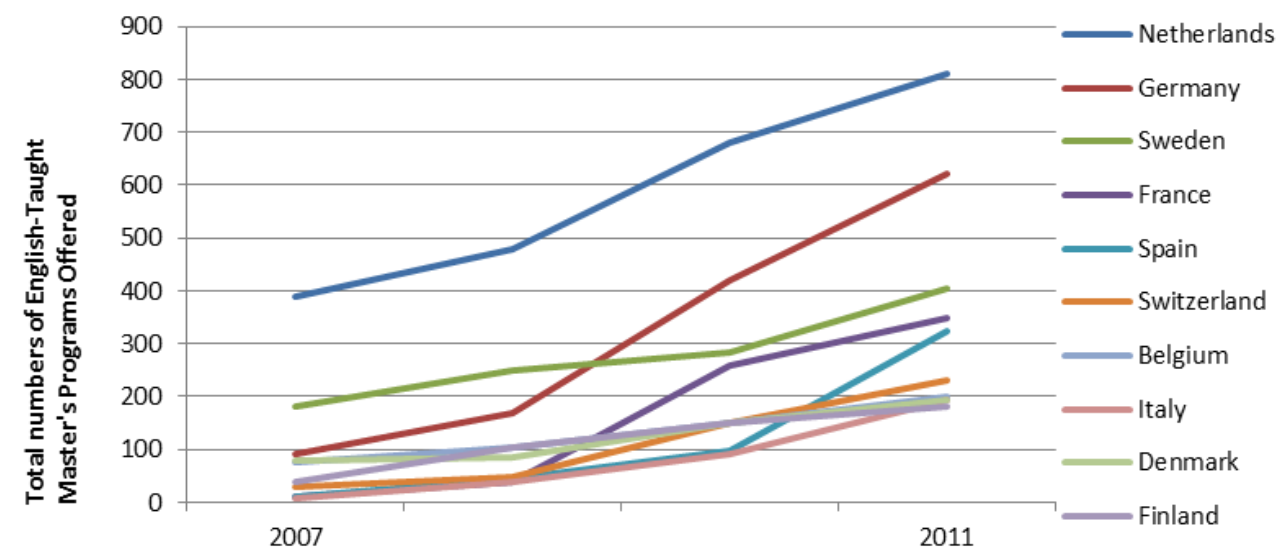

Fig. 2. English-Taught master's programs in nine European countries 
In view of the above, we may conclude that universities in non-English-speaking countries provide a course for integrating Professional English in the curriculum through a variety of ways. However, it should be noted that every higher education institution decides on the instructional model to be used with due consideration of several factors:

- social and academic environment;

- internationalization of higher education;

- competition issues;

- diversified student population;

- increased number of international students;

- academic staff qualification;

- academic staff mobility, etc.

Table 1 presents basic instructional models used in modern universities for teaching Professional English; the difference is the extent to which students are "immersed in the language and professional context".

Table 1.

Integrating Professional English in the curriculum:

\section{Basic instructional models}

\begin{tabular}{|c|c|c|}
\hline Traditional model & $\begin{array}{c}\text { Integrated model (based } \\
\text { on CLIL principles) }\end{array}$ & $\begin{array}{l}\text { English-Taught } \\
\text { programs }\end{array}$ \\
\hline $\begin{array}{l}\text { Professional English courses } \\
\text { are synchronized with } \\
\text { special (content) subjects } \\
\text { included in the } \\
\text { multidisciplinary curriculum. }\end{array}$ & $\begin{array}{l}\text { 1. Teachers of special } \\
\text { (content) subjects are } \\
\text { engaged in creating } \\
\text { Professional English courses. } \\
\text { 2. Authentic "need-to-know" } \\
\text { texts linked to curricular } \\
\text { topics are widely used } \\
\text { (Perez-Vidal, 2013). } \\
\text { 3. CLIL (Content and } \\
\text { Language Integrated } \\
\text { Learning) approach is } \\
\text { utilized, being mutually } \\
\text { beneficial for both content } \\
\text { and language subjects. }\end{array}$ & $\begin{array}{l}\text { 1. English-medium } \\
\text { instruction is used for } \\
\text { teaching all subjects } \\
\text { included in the curriculum. } \\
2 \text {. The quality of teaching } \\
\text { and learning in ETPs } \\
\text { remains questionable due } \\
\text { to an insufficient } \\
\text { command of English of } \\
\text { both parties. }\end{array}$ \\
\hline
\end{tabular}

In this paper, we shall discuss a few innovative e-learning solutions to be applied in the context of the traditional and integrated models. In our view, Englishmedium programs have to be considered as a separate case due to some reasons, particularly as regards professional competence of the related academic staff and correspondingly, the quality of instruction. 
TEACHING PROFESSIONAL ENGLISH AT A MODERN UNIVERSITY: PREPARING STUDENTS FOR THE GLOBAL LABOR MARKET

\section{Some innovative e-learning solutions used in the framework of blended language learning: An overview}

Since learners' needs and authentic tasks are dominant in Professional English courses, many language teachers have integrated the same kinds of technology into their courses, which their learners use in their profession, including the Internet as a source for authentic material and place for authentic communication, virtual conferencing platforms, simulation software, mobile technologies, etc. (Kern, 2013). Applying different educational formats and techniques that can be communicated over the Internet or a Local Area Network has already become an advantage of language teachers. Non-traditional learning environments based on ICT are capable of incorporating diverse scenarios of learning a foreign language. According to Zhao (2003), the use of digital multimedia technologies in language education provide learners and instructors with a) access to authentic linguistic and cultural materials; b) authentic communication in the target language; c) instant and individualized feedback; d) enhanced learner motivation. ICT can also offer great affordances to assessment and, therefore, can broaden teachers' assessment base (Stannard \& Basiel, 2013). In addition, concordancers (software programs that "provide a source of lexico-grammatical information about naturally occurring language") are widely used by English language teachers (Gilbert, 2013).

The extent, to which contemporary universities implement ICT in language learning, may vary significantly; every higher education institution decides on the instructional model to be applied in the educational process on the basis of different factors including attitudes towards e-learning (Stukalina, 2014). Recently, blended learning, as a tool that combines traditional classroom and out-ofclassroom experiences with e-learning activities, has become very popular among educators (Dziuban, Hartman, \& Moskal, 2004). Integration of e-learning activities in the study process follows the tendency that Tarnopolsky (2012) describes as "introducing autonomous language acquisition into the foreign language classroom". It may stimulate learners to "research language on their own", which is regarded by Harmer (2004) as an essential element of language education. By means of blended learning instruments language teachers will be able to enhance the educational environment resources through the use of extra learning resources from the external environment (Stukalina, 2014). A blended English language course should be designed with the constructivist philosophy in mind with a strong 
focus on language use in target situations. It presupposes that constructivist learning enables students construct their own knowledge through active engagement in the learning process (Cooperstein \& Kocevar-Weidinger, 2004). Being a learner-centered instructional approach, constructivism offers students an opportunity to construct their skills through practical experience and real-life activities and simulated activities (Tarnopolsky, 2012).

According to Koohang, Riley, and Smith (2009), the learning design elements include, among other things, conceptual interrelatedness and interdisciplinary learning, investigation, learner's determined goals and objectives and their own previous experiences, learner's self-mediating and control of learning, learner's self-reflection, real world and relevant examples; the collaborative design elements for learning activities comprise learners' collaboration, learners' multiple perspectives (representation of ideas and concepts) and social communication. Online resources stimulated by blended learning make available suitable authentic materials for simulating professional activities and communication (Tarnopolsky, 2012). Moreover, a blended learning language course developed consistently with the constructive approach can be customized to suit the student's individual learning style (Stukalina, 2014).

Blended learning strategies can facilitate the integration of "multi-modal, multi-channel and multi-source" learning, this way assisting students to "develop and improve their learning autonomy" (Alowayr \& Badi, 2014). In the agenda of studying Professional English, a few innovative e-learning solutions aimed at developing basic language skills as by-products of extra-linguistic activities can be utilized (Table 2). They provide various different options that can be successfully employed in the frame of blended language learning.

Table 2

\section{Teaching Professional English in the frame of a blended-learning course: Multiple e-learning solutions}

\begin{tabular}{|l|l|}
\hline \multicolumn{1}{|c|}{ E-learning solution } & \multicolumn{1}{c|}{ Learning Options } \\
\hline Learning management system: & Practical assignments \\
Blackboard, Moodle, Desire2Learn, & Computer-based self-assessment tools \\
Instructure & NanoGong \\
& Forums \\
& Group work \\
& Wikis \\
& Chat \\
& Blogs \\
\hline
\end{tabular}


TEACHING PROFESSIONAL ENGLISH AT A MODERN UNIVERSITY: PREPARING STUDENTS FOR THE GLOBAL LABOR MARKET

\begin{tabular}{|l|l|}
\hline \multicolumn{1}{|c|}{ E-learning solution } & \multicolumn{1}{c|}{ Learning Options } \\
\hline & $\begin{array}{l}\text { Podcasts } \\
\text { Glossaries } \\
\text { Videoconference }\end{array}$ \\
\hline $\begin{array}{l}\text { Organizing inter-higher-school } \\
\text { seminars and conferences on the } \\
\text { base of Skype Technologies, } \\
\text { GoToMeeting, Google Hangouts, } \\
\text { Lync, WebEx }\end{array}$ & Instant messaging \\
& Voice chat \\
& Video chat \\
& Instant file upload \\
\hline Social Networking: & Cloud share \\
Twitter, Facebook, Instagram, & Recording capabilities \\
Google+, LinkedIn, Pinterest, & Chat \\
Tumblr, Reddit & Discussion \\
& Comments \\
\hline Using software applications & Sharing materials \\
developed on web 2.0 tools: & Following up the learning process \\
YouTube, Slide Share, Picasa, & Upload, view, share videos \\
WebM,H.264/MPEG-4 AVC, & Comments \\
Adobe Flash Video & Video Channels \\
\hline
\end{tabular}

Below, we will discuss some e-learning solutions in more detail.

\section{Learning Management Systems (LMS): New opportunities for Professional English teachers and learners}

Learning management systems (LMSs) are commonly utilized in education, having widespread application in the university area as they can support interdisciplinary learning by means of "multimodal representation with realistic content"; they also inspire social negotiation as an important part of learning (Yong Park \& Mills, 2014). LMS can be defined as a "systemic infrastructure" managing the learning process of a whole organization (Watson \& Watson, 2007). A LMS allows teachers to quickly create a course website - a complementary resource that is used for enhancing face-to-face instruction (Gilbert, 2013).

Any learning management system offers Professional English teachers and learners a few techniques that allow assessing and administering the educational process. Such flexible e-learning educational platforms integrate various digital tools and resources; they are intended to make the didactic materials available to students; inherent dynamic document generation enables preserving the confidential information and delivering the document customized for the particular learner (Gumińska \& Madejski, 2007). A LMS can support content in different formats; moreover, reuse of the learning activities can be provided, so time and 
effort can be saved and the cost of improving online content is also decreased (Sharma \& Vatta, 2013). Immediate feedback and remedial practice activities open up new opportunities for those students who are different in terms of learning ability and academic performance; throughout the educational process, teachers will be able to provide systematic training to develop four basic language skills. In the framework of a LMS, Professional English learning can be organized in modules. The online modules used for the blended language course may include, for example, the "creative grammar module", where students can build and test their own models of grammar, or the "text module", where they can develop their language and thinking skills by means of numerous text-based communicative assignments (Sokol, Lasevich, Jonina, \& Dobrovolska-Stoian, 2013).

Table 3 provides more detailed information about most popular Learning management systems and their features. In the higher education market as of fall 2013, Blackboard has been the leading provider with $41 \%$ market share, with Moodle $(23 \%)$, Desire2Learn (11\%) and Instructure ( $8 \%)$ being the next three largest providers (Campus Computing Survey, 2013).

Most popular Learning Management Systems and their features

(Source: www.moodle.org; www.canvasIms.com; www.blackboard.com)

\begin{tabular}{|c|c|}
\hline $\begin{array}{c}\text { A learning } \\
\text { management system } \\
\text { (LMS) }\end{array}$ & Features \\
\hline Blackboard & $\begin{array}{l}\text { Communication: teachers' announcements; real time chat; } \\
\text { discussions; mail and mass emailing } \\
\text { Content: } \\
\text { - Course content } \\
\text { - Calendar } \\
\text { - Learning modules } \\
\text { - Assessments } \\
\text { - Assignments } \\
\text { - Grade Book } \\
\text { - Media Library }\end{array}$ \\
\hline Moodle & $\begin{array}{l}\text { Communication: teachers' announcements } \\
\text { Content: } \\
\text { - Course content } \\
\text { - Calendar } \\
\text { - Learning modules } \\
\text { - Assessments } \\
\text { - Grade Book }\end{array}$ \\
\hline Desire2Learn & $\begin{array}{l}\text { Communication: group collaboration tools; video messaging; } \\
\text { online discussions; instant messaging; integrated social } \\
\text { media profiles and customized notifications } \\
\text { Content: }\end{array}$ \\
\hline
\end{tabular}


TEACHING PROFESSIONAL ENGLISH AT A MODERN UNIVERSITY: PREPARING STUDENTS FOR THE GLOBAL LABOR MARKET

\begin{tabular}{|c|c|}
\hline $\begin{array}{c}\text { A learning } \\
\text { management system }\end{array}$ & Features \\
\hline & $\begin{array}{l}\text { - Course content } \\
\text { - Calendar } \\
\text { - Assessments } \\
\text { - Detailed logging and reporting } \\
\text { - Built-in feedback } \\
\text { - Full-text indexing including powerful external search } \\
\text { - Aggregating materials from external sources } \\
\text { - Totally customized navigation }\end{array}$ \\
\hline $\begin{array}{l}\text { Instructure } \\
\text { Canvas by Instructure }\end{array}$ & $\begin{array}{l}\text { Communication: social media sites } \\
\text { like Facebook and Twitter, Canvas network } \\
\text { Content: } \\
\text { - Course content } \\
\text { - Calendar } \\
\text { - Amazon web-services as a "Cloud" } \\
\text { - Actionable analytics to teachers and administrators } \\
\text { - Open online course Canvas Network }\end{array}$ \\
\hline
\end{tabular}

It is worth mentioning that using one of the above collaborative platforms blended Professional English course developers are able to pay closer attention to students' learning styles taking into account their potential students' strengths and weaknesses (Table 4).

Table 4

\section{E-learning activities integrated in the Professional English blended course}

(Adapted from Stukalina, 2014)

\begin{tabular}{|c|c|}
\hline $\begin{array}{c}\text { Learning style } \\
\text { (based on Harmer, 2004) }\end{array}$ & Supporting e-learning activities \\
\hline $\begin{array}{l}\text { 1. Convergers } \\
\text { - avoid groups } \\
\text { - are more independent } \\
\text { - are analytic and compose } \\
\text { their own structures of learning }\end{array}$ & $\begin{array}{l}\text { - Information seeking for individual use and group } \\
\text { projects } \\
\text { - Unguided interactive assignments and self- } \\
\text { assessment tests } \\
\text { - Developing Glossaries, Wikis, Blogs } \\
\text { - Interactive online language games and quizzes } \\
\text { - Creating mind maps } \\
\text { - Recording audio files } \\
\text { - Developing multimedia instructional materials }\end{array}$ \\
\hline $\begin{array}{l}\text { 2. Conformists } \\
\text { - are predisposed to be } \\
\text { dependent on authority } \\
\text { - are happy in non- } \\
\text { communicative classroom } \\
\text { - prefer to see well-organized } \\
\text { teachers }\end{array}$ & $\begin{array}{l}\text { - Information seeking for individual use and group } \\
\text { projects } \\
\text { - Unguided interactive assignments and self- } \\
\text { assessment tests } \\
\text { - Regular asynchronous online communication with } \\
\text { the teacher } \\
\text { - Developing Glossaries, Wikis, Blogs } \\
\text { - Interactive online language games and quizzes } \\
\text { - Recording audio files }\end{array}$ \\
\hline $\begin{array}{l}\text { 3. Concrete learners } \\
\text { - like social aspects of learning }\end{array}$ & $\begin{array}{l}\text { - Information seeking for individual use and group } \\
\text { projects }\end{array}$ \\
\hline
\end{tabular}




\begin{tabular}{|c|c|}
\hline $\begin{array}{c}\text { Learning style } \\
\text { (based on Harmer, 2004) }\end{array}$ & Supporting e-learning activities \\
\hline $\begin{array}{l}\text { - prefer to learn from direct } \\
\text { experience } \\
\text { - are interested in language as } \\
\text { a means of communication }\end{array}$ & $\begin{array}{l}\text { - Unguided interactive assignments and self- } \\
\text { assessment tests } \\
\text { - Developing Glossaries, Wikis, Blogs } \\
\text { - Interactive online language games and quizzes } \\
\text { - Online discussions: Forums, Chat, Videoconference, } \\
\text { E-mail } \\
\text { - Participating in online group projects: Forums, } \\
\text { Chat, Glossaries, Wikis } \\
\text { - Creating mind maps }\end{array}$ \\
\hline $\begin{array}{l}\text { 4. Communicative learners } \\
\text { - are language use oriented } \\
\text { - are entirely happy to operate } \\
\text { without the guidance of a } \\
\text { teacher }\end{array}$ & $\begin{array}{l}\text { - Information seeking for individual use and group } \\
\text { projects } \\
\text { - Unguided interactive assignments and self- } \\
\text { assessment tests } \\
\text { - Developing Glossaries, Wikis, Blogs } \\
\text { - Interactive online language games and quizzes } \\
\text { - Online discussions: Forums, Chat, Videoconference, } \\
\text { E-mail } \\
\text { - Participating in online group projects: Forums, } \\
\text { Chat, Glossaries, Wikis } \\
\text { - Recording audio files } \\
\text { - creating multimedia instructional materials } \\
\text { - Creating mind maps }\end{array}$ \\
\hline
\end{tabular}

As students can independently organize work with didactic materials, they become more responsible for their learning (Moeller \& Reitzes, 2011). In the frame of a LMS language teachers employ a wide assortment of multimedia resources that are customized to the course syllabus including materials created by students. Student-developed multimedia materials can be used in the context of the constructivist approach to learning; they comprise such audio and video materials, glossaries, blogs, online presentations, etc. That gives an excellent experience in public presenting of personal ideas and, what is probably of the same importance, receiving a feedback. It could be an instant feedback while presenting via online conferences or it can be some kind of written comments from fellow students and teachers. As modern LMSs offer various possibilities to integrate project-based learning in a virtual foreign language classroom, student-developed multimedia materials can be one of the multidisciplinary project outputs. The implementation of such a project will demand the integration of multidisciplinary skills (linguistic and non-linguistic), which is an indispensable attribute of a multidisciplinary educational program. 
TEACHING PROFESSIONAL ENGLISH AT A MODERN UNIVERSITY: PREPARING STUDENTS FOR THE GLOBAL LABOR MARKET

\section{Social networking and software applications developed on web}

\section{0 tools: Using more competitive e-learning solutions}

As distinguished from other e-learning solutions, learning in a LMS is organized as separate study courses. A LMS typically serves as the online platform for course syllabus realization, handouts distribution, management of assignments, course discussions (Zhao Du et al., 2013). Nevertheless, the global learning scene is now being shaped by digital communication tools, pervasive networked applications, saying nothing about the changing characteristics, needs and requirements of modern students. This indicates that digital-age students need an active learning experience that is social, participatory and supported by plenty of media (McLoughlin \& Lee, 2010).

In this context, more competitive e-learning solutions can come into play. The Web 2.0 culture is characterized by increased online participation: blogs are mainly made up of user-created content, wikis enable numerous users to contribute to a growing knowledge base, and social networks let users to create online communities of shared interests (Stevenson \& Liu, 2010). Communication with instructors and fellow students goes far beyond the classroom, speeds up the learning process as a language learner can get a feedback from enormous audiences in a matter of minutes. Language study dramatically depends on using language in communication, and web 2.0 tools give excellent opportunities to do that.

Today, educators are increasingly using social software for meeting the changing needs of their learners; the learning experiences made possible through social software tools are dynamic, driven by students' interests and have the potential to support self-regulated learning (McLoughlin \& Lee, 2010). Social software incorporates shared participation in the creation of information and supports better group interaction (Zhao Du et al., 2013). The results of the research project "Learning 2.0 - the Impact of Web 2.0 Innovations on Education and Training in Europe" (Redecker et al., 2009), demonstrate that social networking tools "support the exchange of knowledge and material; facilitate community building, providing teachers and learners with social environments that offer assistance and (emotional) support; and provide platforms for collaboration, allowing teachers and learners to jointly develop educational content". 
The most popular social networking sites include Facebook, Twitter, Pinterest, Instagram, Tumb/r, and others. Facebook represents a huge potential market for learners' social media efforts. According to Facebook statistics retrieved in July, 2015, worldwide, there are over 1.44 billion monthly active Facebook users, which is a 13 percent increase year over year. According to the results of the study performed by Irwin, Ball, \& Desbrow (2012), students incorporate Facebook into the learning process and perceive benefits through enhanced communication, interaction, and flexibility in course content delivery. There have been developed a few English language learning sites that use social networking features: Babbel (http://www.babbel.com/learn-english-online), Livemocha (http://livemocha.com), etc. Also we cannot avoid professional social networking such as LinkedIn - the business-oriented social networking website - when we are talking about professional web 2.0 tools. Those interactive sites help to compare work skills and give the idea what professional trainings and learning courses are of a high demand in the job market, which becomes particularly important in the context of intercultural exchange activities. To join the professional community that operates in English means an instant immersion in a correct language environment. Public space requires a deep professional awareness as communication goes in a real time and a student needs to keep high professional English language standards to be successful in the community. In the perspective of language learning, other software applications developed on Web 2.0 tools such as Picasa, YouTube, Slide Share and others - also allow users (both students and teachers) to contribute to the web page content, to interact with other users and to store personal information.

\section{Conclusions}

In this paper, the authors have provided an overview of a few e-learning solutions focusing mainly on the many benefits they offer to both teachers and students in the agenda of studying Professional English. The technologies discussed above have changed the way the subject is taught in the frame of a multidisciplinary educational program, English language learning being an indispensable component of contemporary education.

Modern e-learning solutions enrich face-to-face instruction and teacherlearner communication by means of a wide variety of computer-based and web- 
TEACHING PROFESSIONAL ENGLISH AT A MODERN UNIVERSITY: PREPARING STUDENTS FOR THE GLOBAL LABOR MARKET

based resources including multimedia content for classrooms and projects (developed by professionals and learners themselves). Moreover, they support individualized learning and can match different learning styles giving students more freedom and more responsibility at the same time. Learners can naturally collaborate online using Professional English in real-life situations, which is vital for developing excellent language skills necessary for their career development in the global labor market. The above e-learning solutions provide students with a number of opportunities to develop a wide assortment of other employability skills, including team working skills, within a profession-oriented environment.

It should also be emphasized that educators may come across some systematic problems in the process of selecting e-learning solutions and online materials for supporting the learning process. Nowadays the web offers us an enormous quantity of textbooks, video files, online courses, YouTube presentations, and all kinds of information that might be used in the classrooms. But the problem is how to distinguish the really good ones, or even those that students really need for performing the current task. Materials can contain low language comments, be aggressive and rude, include trolling and spam. One of the reasons we cannot trust online sources or at least the great majority of them is that there is no common system of ratings. You Tube video can have a very high level of popularity, but that does not mean it is popular among our target audience. The only solution for this problem is to use materials that the professional communities rate very high. Obviously that means that somebody else should test it before giving conclusions and references. And we can help greatly if everyone tests some online open-source materials and shares their experience on the wall of comments or any other professional network. Thus, much depends on the professionalism and qualification of the teacher. But that is a separate topic, which demands further careful consideration.

\section{References}

Alowayr, A., \& Badi, A. (2014). Review of monitoring tools for e-learning platforms. International Journal of Computer Science \& Information Technology (IJCSIT), 6(3), 79-86.

Brenn-White, M. \& van Rest, E. (2012). English-Taught Master's Programs in Europe: New Findings on Supply and Demand, A Briefing Paper from IIE's 
Center for Academic Mobility Research [PDF document]. Retrieved from http://www.iie.org/Research-and-Publications/Publications-and-

Reports/IIE-Bookstore/English-Language-Masters-Briefing-Paper.

Campus Computing Survey: The National Survey of Computing and Information

Technology (2013). Campus Computing, October 2013. Retrieved from http://www.campuscomputing.net/sites/www.campuscomputing.net/files/

CampusComputing2013_1.pdf.

Com(2007) 184 final. Framework for the European Survey on Language Competences, Communication from the Commission to the Council. Retrieved from http://eur-lex.europa.eu/legal-content/EN/TXT/ ?uri=CELEX:52007DC0184.

$\operatorname{COM(2013)} 499$ final. European Higher Education in the World, Communication from the Commission to the European Parliament, the Council, the European Economic and Social Committee and the Committee of the Regions. Retrieved from http://eur-lex.europa.eu/legal-content/EN/TXT/ ?uri=COM:2013:0499:FIN.

Cooperstein, S., E., \& Kocevar-Weidinger E. (2004). Beyond active learning: a constructivist approach to learning. Reference Services Review, 32(2), 141-148.

Dziuban, C. D., Hartman, J. L., Moskal, P. D. (2004). Blended Learning: EDUCASE Centre for Applied Research Bulletin, 2004(7). Retrieved from http://net.educause.edu/ir/library/pdf/ERB0407.pdf.

Evans, D. L., Goodnick S. M., \& Roede R., J. (2003). ECE curriculum in 2013 and beyond: Vision for a metropolitan public research university. IEEE Transactions on Education, 46(4), 420-428.

Four Year Salary Survey by Lifeworx (2009-2013). Retrieved from https://lifeworx.com/en/resources/four-year-salary-survey-by-lifeworx.

Gilbert, J. (2013). English for Academic Purposes. In G. Motteran (Ed.), Innovations in learning technologies for English language teaching (pp. 117-143). London: British Council. Retrieved from https://www.teachingenglish.org.uk/sites/teacheng/files/C607\%20Informa tion\%20and\%20Communication_WEB\%200NLY_FINAL.pdf.

Gumińska, M., \& Madejski, J. (2007). Web based e-learning platform as a source of the personalised teaching materials. Journal of Achievements in Materials and Manufacturing Engineering, 24(2), 227-230. 
TEACHING PROFESSIONAL ENGLISH AT A MODERN UNIVERSITY: PREPARING STUDENTS FOR THE GLOBAL LABOR MARKET

Harmer, J. (2004). The Practice of English Language Teaching, $3^{\text {rd }}$ edition. UK: Pearson Education Limited.

Higher Education to 2030 (2009). Executive Summary, Vol. 2: Globalisation. OECD Publishing. Retrieved from http://www.mfdps.si/Files/Knjiznica/higher\% 20educational\%202030\%200ECD.pdf.

Irwin, Ch., Ball, L., \& Desbrow, B. (2012). Students' perceptions of using Facebook as an interactive learning resource at university. Australasian Journal of Educational Technology, 28(7), 1221-1232. Retrieved from http://www98.griffith.edu.au/dspace/bitstream/handle/10072/47627/8056 6_1.pdf?sequence=1.

Kern, N. (2013). Technology-integrated English for Specific Purposes lessons: reallife language, tasks, and tools for professionals. In G. Motteran (Ed.), Innovations in learning technologies for English language teaching (pp. 89115) [PDF document]. Retrieved from https://www.teachingenglish.org.uk/ sites/teacheng/files/C607\%20Information\%20and\%20Communication_WE B\%200NLY_FINAL.pdf.

Koohang, A., Riley, L., \& Smith, T. (2009). E-Learning and Constructivism: From Theory to Application. Interdisciplinary Journal of E-Learning and Learning Objects, Vol. 5.

Lam, Q., K.H., \& Wächter, B. (2014). Executive summary. In B. Wächter, F. Maiworm (Eds.). English-Taught Programmes in European Higher Education: The State of Play in 2014 (pp. 15-24) [PDF document]. Retrieved from http://www.lemmens.de/fileadmin/user_upload/Verlag/ Buecher/ACA_Download_PDFs/2014_English_Taught.pdf.

Mcloughlin. C., \& Lee, M., J., W. (2010). Personalized and self-regulated learning in the web 2.0 era: International exemplars of innovative pedagogy using social software. Australasian Journal of Educational Technology, 26(1), 2843.

Moeller, B., \& Reitzes, T. (2011). Integrating technology with student-centred learning. A Report to the Nellie Mae Education Foundation [PDF document]. Retrieved from http://www.nmefoundation.org/getmedia/befa9751-d8ad47e9-949d-bd649f7c0044/Integrating-Technology-with-Student-CenteredLearning?ext $=$. pdf.

Perez-Vidal, C. (2013). Perspectives and lessons from the challenge of CLIL experiences. In Ch. Abello-Contesse, P. M. Chandler, M. D. López-Jiménez., 
R. Chacón-Beltrán (2EDS.) Bilingual and Multilingual Education in the $21^{\text {st }}$ Century: Building on Experience. UK: CPI Group.

Redecker, Ch., Ala-Mutka, K., Bacigalupo, M., Ferrari, A., \& Punie, Y. (2009). Learning 2.0: The Impact of Web 2.0 Innovations on Education and Training in Europe, Final Report [PDF document]. Retrieved from http://ftp.jrc.es/EURdoc/JRC55629.pdf.

Sharma, A., \& Vatta, S. (2013). Role of Learning Management Systems in Education. International Journal of Advanced Research in Computer Science and Software Engineering, 3(6), 997-1002.

Sokol, A., Lasevich, E., Jonina, R., \& Dobrovolska-Stoian, M. (2013). A thinkingbased blended learning course in an upper-secondary school in Latvia. In B. Tomlinson \& C. Whittaker (Eds.), Blended Learning in English Language Teaching: Course Design and Implementation (pp. 189-199). London: British Council.

Stannard, R, \& Basiel, A. (2013). A practice-based exploration of technology enhanced assessment for English language teaching. In G. Motteran (Ed.), Innovations in learning technologies for English language teaching (pp. 145-173) [PDF document]. Retrieved from https://www.teachingenglish.org.uk/sites/teacheng/files/C607\%20Informa tion\%20and\%20Communication_WEB\%200NLY_FINAL.pdf.

Stevenson, M., P., \& Liu, M. (2010). Learning a Language with Web 2.0: Exploring the Use of Social Networking Features of Foreign Language Learning Websites. CALICO Journal, 27(2). Retrieved from https://www.calico.org/ html/article_791.pdf.

Stukalina, Y. (2009). Highly integrated educational environment as a precondition for multidisciplinary education. In J. A. Johnson \& M. L. Higgins (Eds.), Proceedings of the $13^{\text {th }}$ World Conference "Creating a Global Culture of Peace Strategies for Curriculum Development and Implementation" (pp. 211-224). Alaska: International Educational Initiatives, Juneau.

Stukalina, Y. (2011). Creating a constructive educational environment to foster language learning in a higher technical school: Using a blended-learning approach. Proceedings of the 5th International Conference "Languages for Work and Life: Challenge for Teachers and Learners" [PDF document]. Retrieved from http://lkpa.Ihosting.info/straipsniai/st_16.pdf. 
TEACHING PROFESSIONAL ENGLISH AT A MODERN UNIVERSITY: PREPARING STUDENTS FOR THE GLOBAL LABOR MARKET

Stukalina, Y. (2014). Teaching ESP in the blended format: Using non-traditional learning environments. Language for international communication: Linking interdisciplinary perspectives (pp. 177-189). Latvia: University of Latvia Press.

Tarnopolsky, O. (2012). Constructivist Blended Learning Approach to Teaching English for Specific Purposes. DE GRUYTER OPEN. Retrieved from http://www.degruyter.com/view/product/205438.

Watson, W. R., \& Watson, S. L. (2007). An argument for clarity: what are learning management systems, what are they not, and what should they become?, TechTrends, 51(2), 28-34.

Yong Park, J., \& \& Mills, A. (2014). Enhancing Interdisciplinary Learning with aLearning Management System. MERLOT Journal of Online Learning and Teaching, 10(2). Retrieved from http://jolt.merlot.org/vol10no2/ park_0614.pdf.

Zhao Du, Xiaolong Fu, Can Zhao, Qifeng Liu, \& Ting Liu (2013). Interactive and Collaborative E-Learning Platform with Integrated Social Software and Learning Management System. Chapter 2. In Lu, W., Cai, G., Liu W., Xing, W. (Eds.), Proceedings of the International 2102 Conference on Information Technology and Software Engineering (pp. 11-18). Software Engineering \& Digital Media Technology.

Zhao, Y. (2003). Recent Developments in Technology and Language Learning: A Literature Review and Meta-analysis. CALICO Journal, 21(1). Retrieved from

http://www.elthillside.com/sites/default/files/articles/Recent\%20Developm ents\%20in\%20Technology\%20and\%20Language\%20Learning.pdf.

\section{Online resources}

Blackboard. Retrieved August 20, 2015 from:

http://www.blackboard.com/learning-management-system/blackboard-learn.aspx. Moodle. Retrieved August 10, 2015 from: https://moodle.org/.

Brightspace. Retrieved July 11, 2015 from: http://www.brightspace.com/.

CanvasIms. Retrieved July 25, 2015 from: http://www.canvaslms.com/.

Zephoria. Retrieved August 5, 2015 from: https://zephoria.com/top-15-valuablefacebook-statistics/. 


\section{Yulia Stukalina}

Latvijos transporto ir telekomunikaciju institutas, Latvija; stukalina.j@tsi.Iv

Olga Zervina

Latvijos transporto ir telekomunikaciju institutas, Latvija; olgaingram@msn.com

\section{PROFESINĖS ANGLU KALBOS MOKYMAS ŠIUOLAIKINIAME UNIVERSITETE: STUDENTU RENGIMAS GLOBALIAI DARBO RINKAI}

Santrauka. Pagrindinis šiuolaikiniu universitetu tikslas - suteikti studentams ivairiu gebejjimu, būtinu tarptautinèje darbo rinkoje, iskaitant ir puikią kalbinę kompetenciją. Šiame kontekste anglu kalbos mokymasis aukštojo mokslo institucijoje tampa privalomu daugiadisciplinio ugdymo elementu. Daugiadisciplinio mokymo programa charakterizuoja ivairiu sričiu integracija - tokios programos struktūroje inkorporuojamos ivairios kalbos bei profesijos dalyku mokymo schemos. Šiuolaikiniuose universitetuose anglu kalbai turètu būti skiriamas kompetentingos kalbos vaidmuo, mokant vadybos, ekonomikos, architektūros, žmogaus teisiu, informaciniu technologiju ir daugelio kitu specializuotu dalyku. Daugiadisciplineje programoje profesinès anglu kalbos dalykas turi atitikti reikalavimus tu žmoniu, kurie, siekdami efektyvios komunikacijos, vartos anglu kalba tarptautiniame profesinès srities kontekste ir taip pat tu žmoniu, kuriems anglu kalbos mokèjimas darbinejje veikloje yra esminis profesinio augimo elementas. Straipsnyje nagrinejamos kelios reikšmingos profesinès anglu kalbos mokymo šiuolaikiniame universitete problemos. Pateikiami keli inovatyvūs e. mokymosi sprendimai, kurie gali būti panaudojami daugiadisciplinès mokymo programos struktūroje, siekiant sustiprinti studentu profesinès komunikacijos igūdžius, kad jie galètu tinkamai pasiruošti pasaulinei darbo rinkai. Straipsnyje teigiama, kad mišrus požiūris i kalbos mokymą yra daug žadanti efektyvi priemonè, siekiant ¡vairiu kalbiniu igūdžiu. Akcentuojamas anglu kalbos vartojimas realiame gyvenime.

Pagrindinès sąvokos: daugiadisciplinis mokymas, profesinè anglu kalba, e. mokymosi sprendimai, mišrus mokymasis. 